\title{
Climate change as the biggest threat to public health in southern Africa and measures to reduce its impacts
}

\author{
Fanuel M. Bickton
}

Year 3 Student, Department of Physiotherapy, College of Medicine, University of Malawi, Blantyre, Malawi

Correspondence to: fmbickton@stud.medcol.mw

\begin{abstract}
Introduction
The southern African region is defined in political terms as those countries that are members of the Southern African Development Community (SADC). ${ }^{1}$ Currently there are fifteen member states of the SADC: Angola, Botswana, the Democratic Republic of Congo (DRC), Lesotho, Madagascar, Malawi, Mauritius, Mozambique, Namibia, the Seychelles, South Africa, Swaziland, Tanzania, Zambia, and Zimbabwe. ${ }^{1-3}$
\end{abstract}

Figure 1: Members states of the Southern African Development Community (SADC)

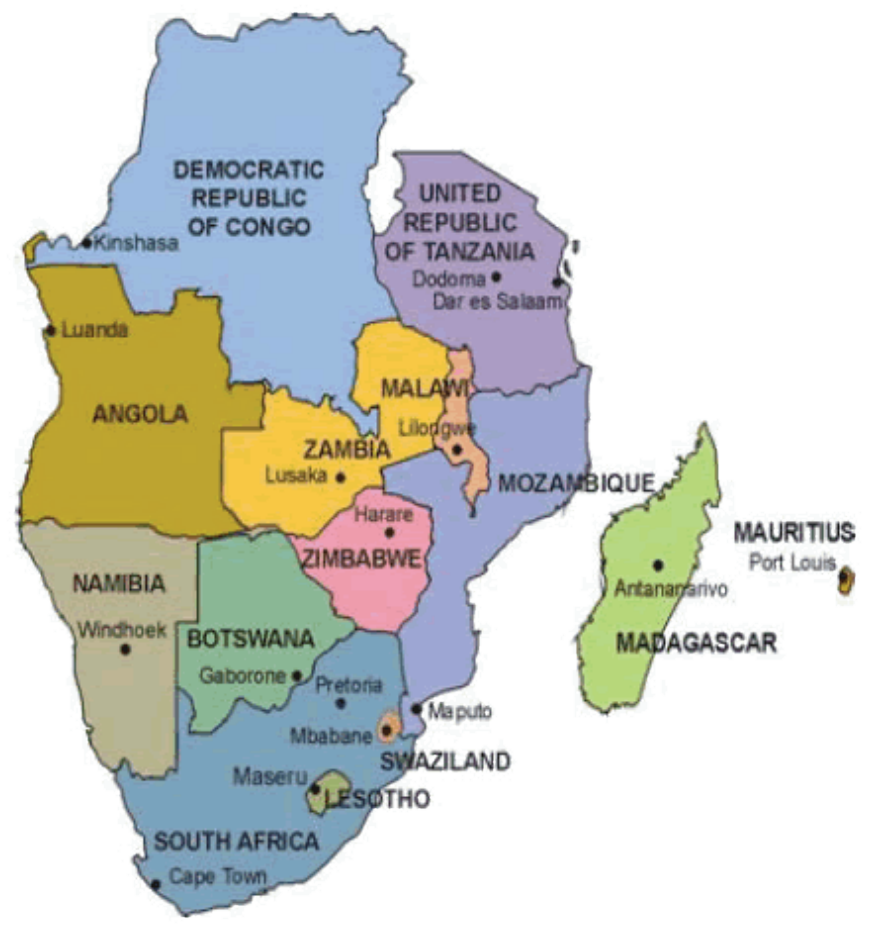

The Lancet has declared climate change and its impact on health as the biggest global health threat of the 21 st century. ${ }^{3}$ Southern Africa contributes little to climate change, but it is widely recognised as one of the most vulnerable regions to climate change because of low levels of adaptive capacity, combined with a high dependence on rain-fed agriculture., Against this background, this essay presents climate change as the biggest threat to public health in the region. Potential options to mitigate the effects of this threat are also presented in the article.

\section{Identifying the biggest threat to public health in southern Africa}

Public health threats are events with potential to adversely affect the health of human populations, especially those that may spread internationally or present a serious and direct danger. ${ }^{7}$ Literature shows a vast range of often interconnected issues identified as threats to public health in southern Africa, ${ }^{1}$ and it is difficult to do them all justice here. However, on the basis of the definition of public health threats above and from what literature reveals about the current state of public health in southern Africa, HIV/ AIDS and climate change stand out in this essay, with the latter being the biggest threat.

The epicenter of the global HIV/AIDS epidemic is southern Africa. ${ }^{8}$ However, there are encouraging signs that the impact of the epidemic in the region is slowing, evidenced by declining new infection rates. This progress is mainly due to the region's wide campaign of condom use and wide extent of antiretroviral therapy (ART) efforts. ${ }^{9}$ On the other hand, while the entire world is struggling with the challenges presented by the changing global climate, southern Africa is uniquely susceptible to the impacts of climate change. ${ }^{10}$ The region is a predominantly semi-arid region with high rainfall variability, characterised by frequent droughts and floods. Climate change refers to a change in the average weather experienced in a particular region or location. ${ }^{2}$ Temperatures in southern Africa have increased and rainfall patterns have changed, with some parts receiving little to no rain and others experiencing intense daily rainfall. El Niño events have also been observed in the region. With projected trends, the region's warming is likely to exceed average global warming. There will be drier conditions over a large part of the region, severe droughts, and intense flooding. ${ }^{10}$

\section{Climate change and natural disasters in southern Africa}

The heavy seasonal rainfall of December 2014 caused flooding in southern Africa. As of 16 Jan 2015, 135,000 people had been affected in Malawi, Mozambique, Madagascar, and Zimbabwe. ${ }^{12}$ With 638,000 people affected by floods, Malawi declared a state of disaster on 13 January $2015 .{ }^{13}$ On 12 January 2015, an institutional red alert was declared in Mozambique after a period of heavy rainfall causing severe flooding across central and northern Mozambique, with 373,026 people being affected. In Zimbabwe, approximately 6000 people (1200 households) were affected by widespread floods, of which 2500 people (500 households) were in urgent need of assistance. ${ }^{13}$ In Madagascar, the flooding in the greater Antananarivo worsened, and on 27 February 2015, a red alert was declared; 2000 households $(10,000$ people) were affected by the floods. ${ }^{14}$ In all these countries, deaths of people due to flood-related cholera were also reported.

\section{Climate change, food insecurity, and malnutrition in southern Africa}

Agriculture is the backbone of southern Africa in sustaining livelihoods and food security, and climate change is its major threat. ${ }^{15}$ Currently, southern Africa is in the grip of an intense drought that has expanded and strengthened since the earliest stages of the 2015-2016 agricultural season, 
driven by one of the strongest El Niño events of the last 50 years. Nearly 29 million people are currently food insecure in the region, mainly due to the carryover effects of the past poor harvest season combined with other structural factors. The outcome from this is malnutrition, especially in people with greater nutritional needs, including children, nursing mothers, the elderly and those living with tuberculosis and/ or HIV and AIDS. ${ }^{16}$

\section{Climate change and infectious diseases in southern Africa}

According to a 2009 report published by Action for Southern Africa (ACTSA), climate change is exacerbating the effects of infectious diseases in southern Africa. ${ }^{5}$ High temperatures, longer rainy seasons, and inadequate rain water drainage tend to create the perfect incubation conditions for mosquitoborne diseases, particularly malaria. Southern African countries that currently do not suffer prevalent malaria, such as South Africa, Lesotho, and Swaziland, will become at great risk. With food insecurity heightened, HIV/AIDS treatment, which is reliant on good nutrition, will become increasingly difficult, leading to many more deaths. Cholera is on the increase again in Africa, especially in Zimbabwe, where a lack of clean water is perpetuated by the country's weak detection and response capacities. In addition, according to Luis Sambo, World Health Organization(WHO) Regional Director for Africa, the incidence of meningitis is increasing throughout the region due to climate changes enabling the airborne disease-causing bacteria to spread, causing further challenges for the medical sector. Also, studies show a strong association between the region's high temperatures and increased episodes of diarrhoeal diseases in adults and children. ${ }^{17,18}$

\section{Addressing impacts of climate change on public health in southern Africa}

Addressing climate change in southern Africa requires a twofold approach of mitigation and adaptation. ${ }^{5}$

\section{Mitigation: Reducing the cause}

Mitigation refers to measures undertaken to reduce or eliminate greenhouse gas emissions into the atmosphere in order to decrease global temperature. ${ }^{6}$ In southern Africa, South Africa is by far the biggest carbon emitter. However, the Group of 20 (G20) countries are the principal culprits for the rising green house gas emissions. These industrialised countries can use the following mitigation strategies in order to reverse the condition: energy efficiency and conservation, switching from fossil fuels to cleaner and renewable energy sources, capturing methane from coal mines and land fill sites, and changing land use practices. ${ }^{5,19}$

\section{Adaptation: Reducing the risk}

Some impacts of climate change on public health are inevitable and cannot be reduced through mitigation. Here, southern Africa needs to adapt. Adaptation strategies reduce the risks posed by climate change to people's lives and livelihoods. For instance, Malawi has developed a National Adaptation Programme of Action to increase climate monitoring while improving community resilience; agricultural production; and preparedness for droughts, floods, and other extreme weather events. ${ }^{20}$

\section{Conclusion and recommendations}

This article has described climate change as the biggest threat to public health in southern Africa as well as measures against it. As a recommendation, literature shows that much of the research work linking public health to climate change has been conducted outside the southern African region, so there is need for locally driven initiatives that integrate local context in understanding the impact of climate change on the health sector. ${ }^{21}$

\section{Acknowledgements}

With this essay, Fanuel Bickton won the 2016 Medic to Medic Hurst Essay Prize. This year's essay topic discussed the biggest threat to public health in southern Africa and how it could be overcome. The other prize winners were third-year pharmacy student, Titus Kapalamula (2nd prize), and fourth-year physiotherapy student, Juliet Kakowa (3rd prize). Highly Commended essays were written by fifth year MBBS student, Madalitso Zulu, and third-year pharmacy student, Thokozire Phiri.

Medic to Medic is a UK-based charity that supports students training to be health professionals in southern Africa. They target promising students who are at risk of dropping out from their courses due to financial difficulties or family background. They link students to health professionals in the UK through regular donations and correspondence. They are currently the biggest sponsorship programme at the University of Malawi College of Medicine and have sponsored $5 \%$ of Malawian doctors. In Malawi, Medic to Medic has also sponsored nurses, physiotherapists, pharmacists, clinical officers, and health managers through to qualification. For more information or to help, please visit www.medictomedic.org.uk.

\section{References}

1. Cawthra G. Southern Africa: threats and capabilities. New York: IPI Publications; 2008. 12 p.

2. Davis CL, editor. Climate risk and vulnerability: a handbook for Southern Africa. Council for Scientific and Industrial Research. Pretoria: Council for Scientific and Industrial Research; 2011. 92 p.

3. World Hydrological Cycle Observing System (WHYCOS). Project implemented: SADC-HYCOS phase I [Internet].WHYCOS Portal (@ WMO). Geneva: World Meteorological Organization; Available from: http://www.whycos.org/whycos/projects/implemented/sadc-hycosphase-i

4. Costello A, Abbas M, Allen A, Ball S, Bell S, Bellamy R, et al. Managing the health effects of climate change: Lancet and University College London Institute for Global Health Commission. Lancet. Elsevier; 2009 May 16;373(9676):1693-733.

5. Action for Southern Africa (ACTSA). ACTSA briefing paper: climate change in southern Africa. London; 2009.

6. Intergovernmental Panel on Climate Change (IPCC). Climate change 2007: impacts, adaptation and vulnerability: contribution of Working Group II to the fourth assessment report of the Intergovernmental Panel on Climate Change. Parry M, Canziani O, Palutikof J, van der Linden P, Hanson C, editors. Vol. 4. 2007. 976 p.

7. World Health Organization. The world health report 2007 : a safer future : global public health security in the 21 st century. Geneva: WHO Press; 2007.

8. Sawers L, Stillwaggon E. Understanding the Southern African "anomaly": poverty, dndemic disease and HIV. Dev Change. 2010;41(2):195-224.

9. Holloway A, Chasi V, de Waal J, Drimie S, Fortune G, Mafeluka $\mathrm{G}$, et al. Humanitarian trends in southern Africa: challenges and opportunities. Rome: FAO; 2013.

10. Southern African Development Community (SADC). Climate change adaptation [Internet]. www.sadc.int. 2012. Available from: http://www.sadc.int/themes/meteorology-climate/climate-changeadaptation/ 
11. Intergovernmental Panel on Climate Change (IPCC). The IPCC's fifth assessment report: What's in it for Africa? Executive summary. In: Stocker TF, Qin D, Plattner GK, Tignor M, Allen SK, Boschung J, et al., editors. Climate change 2013: the physical science basis Contribution of Working Group I to the fifth assessment report of the Intergovernmental Panel on Climate Change. Cambridge: Cambridge University Press; 2013. p. 33.

12. United Nations Office for the Coordination of Humanitarian Affairs. Southern Africa: floods and cyclones update (as of 16 Jan 2015) storm category [Internet]. reliefweb.int. 2015. Available from: http:// reliefweb.int/map/malawi/southern-africa-floods-and-cyclones-update16-jan-2015

13. United Nations Office for the Coordination of Humanitarian Affairs Malawi: floods emergency appeal (MDRMW011), six month operations update [Internet]. reliefweb.int. 2015. Available from: http://reliefweb. int/report/malawi/malawi-floods-emergency-appeal-mdrmw011-sixmonth-operations-update

14. United Nations Office for the Coordination of Humanitarian Affairs. Madagascar: yclone Chedza emergency plan of action final report DREF $\mathrm{n}^{\circ}$ MDRMG011 [Internet]. reliefweb.int. 2016. Available from: http://reliefweb.int/report/madagascar/madagascar-cyclone-chedzaemergency-plan-action-final-report-dref-n-mdrmg011

15. United Nations Office for the Coordination of Humanitarian Affairs. Southern African Food and Nutrition Security Working Group (FSNWG): issue 4, November 2015 [Internet]. Reliefweb.Int. 2015. Available from: http://reliefweb.int/report/south-africa/southernafrican-food-and-nutrition-security-working-group-fsnwg-issue-4
16. Wlokas $\mathrm{H}$. The impacts of climate change on food security and health in southern Africa. J Energy South Africa. 2008;19(4):12-20.

17. Nchito M, Kelly P, Sianongo S, Luo NP, Feldman R, Farthing M, et al. Cryptosporidiosis in urban Zambian children: an analysis of risk factors. Am J Trop Med Hyg. 1998 Sep;59(3):435-7.

18. Thompson AA, Matamale L, Kharidza SD. Impact of climate change on children's health in Limpopo Province, South Africa. Int J Environ Res Public Health. 2012 Mar;9(3):831-54.

19. van Schalkwyk M. Media statement by Marthinus van Schalkwyk, Minister of Environmental Affairs and Tourism, Cape Town 28 July 2008. Cape Town: Department of Environmental Affairs and Tourism; 2008.

20. Human Development Report Office (HDRO). Human development report 2007/2008: fighting climate change: human solidarity in a divided world. New York: Palgrave; 2007.

21. Amis MA, Jalloh A, Hachigonta S. Review of research and policies for climate change adaptation in the agriculture sector in Southern Africa. Brighton (UK): International Development Research Centre; 2014. 